\title{
DIGITAL BANKING REFLECTION AND ZAKAT ACCOUNTABILITY SHARIA BANKING IN INDONESIA
}

\author{
Pertiwi Utami \\ Postgraduate Student at Sharia Economic of Universitas Islam Negeri Radin \\ Intan, Lampung, Indonesia \\ utamipertiwi89@gmail.com
}

\begin{abstract}
Digital banking and the accountability of good zakat can increase interest in paying zakat on the benchmarking of sharia. On the other hand, technological advances such as the use of artificial intelligence make the role of human resources shifted. Even though human resources (labor) are one of the potential sources of zakat revenue. Zakat literacy and interest in paying zakat are also low in Islamic banking. The researcher did not find zakat data in statistical reports on Islamic banks nationally. It seems that it was only found in the presentation of reports about the sources and uses of private Islamic bank zakat funds. This can lead to the perception that Islamic banks do not optimally manage zakat. Through literature studies, researchers provide a solution to how zakat management can be done to increase interest in paying zakat but can still maintain the use of human resources (work). The conclusion obtained is that interest in paying zakat on Islamic banks cannot be maximally realized if it is not supported by internal efforts. Efforts that can be made are transparency of zakat reports, increased literacy, acceleration and optimization of digital management of Islamic bank zakat.
\end{abstract}

Keywords: Digital Banking, Accountability Zakat, Syariah Banking

\begin{abstract}
Abstrak: Perbankan digital dan pertanggungjawaban zakat yang baik dapat meningkatkan minat membayar zakat atas tolok ukur syariah. Di sisi lain, kemajuan teknologi seperti penggunaan kecerdasan buatan membuat peran sumber daya manusia bergeser. Padahal sumber daya manusia (tenaga kerja) merupakan salah satu sumber potensial pendapatan zakat. Literasi zakat dan minat membayar zakat juga rendah di perbankan Islam. Peneliti tidak menemukan data zakat dalam laporan statistik pada bank syariah secara nasional. Tampaknya itu hanya ditemukan dalam presentasi laporan tentang sumber dan penggunaan dana zakat bank syariah swasta. Hal ini dapat menimbulkan persepsi bahwa bank syariah tidak secara optimal mengelola zakat. Melalui studi literatur, peneliti memberikan solusi bagaimana manajemen zakat dapat dilakukan untuk meningkatkan minat membayar zakat tetapi masih dapat mempertahankan penggunaan sumber daya manusia (pekerjaan). Kesimpulan yang diperoleh adalah bahwa minat membayar zakat pada bank syariah tidak dapat direalisasi secara maksimal jika tidak didukung oleh upaya internal. Upaya yang dapat dilakukan adalah transparansi laporan zakat, peningkatan literasi, akselerasi dan optimalisasi manajemen digital zakat bank syariah.
\end{abstract}

Kata Kunci: Perbankan Digital, Akuntabilitas Zakat, Perbankan Syariah 
Pertiwi Utami:

Digital Banking Reflection and Zakat Accountability Sharia Banking in Indonesia

\section{INTRODUCTION}

Digitalization of the economy continues to innovate and develop to face global economic competition, efforts to build halal ecosystems and support economic empowerment of the community. ${ }^{1}$

One of the concerns is the Sharia Banking Industry in Indonesia which is experiencing tremendous challenges facing stiff competition from digital bankingbased services. ${ }^{2}$ In addition, the achievement of the development of Islamic banks to date has not been able to meet the expected targets. ${ }^{3}$ With the use of technology, it is hoped that banking sharia will make a variety of new innovations, for example developing digital-based bank services to support the performance of Islamic financial institutions (Vebiana, n.d.). "The level of customer satisfaction in using financial technology can affect their loyalty to banks" 4 "The development of digital banking culture now has a very significant role in financial inclusion. This is the reason why banks are increasingly interested in utilizing digital technology as much as possible. ${ }^{5}$

As there is in good corporate governance as a financial institution based on sharia principles, companies or financial institutions are required to fulfill zakat. ${ }^{6}$ In the Statement of Financial Accounting Standards (PSAK) number 109 concerning accounting for zakat, infaq and sadaqah it contains the standard form of reports on sources and uses of zakat funds. From the report, it can also be seen the potential of zakat in banking and how much zakat has been realized. "The potential for collecting zakat funds originating from Islamic banking in Indonesia is very significant. Based on Sharia Banking Statistics data until April 2018, the labor force for sharia banking as a potential source of zakat receipt by the Amil Zakat Institution is as follows. "(Bank Licensing and Banking Information Administration and Publication Department Deputy Director. ${ }^{7}$

Table 1.1 Potential of Syariah Banking Zakat

\begin{tabular}{|l|l|l|l|l|}
\hline Indicator & 2015 & 2016 & 2017 & April 2018 \\
\hline
\end{tabular}


Pertiwi Utami:

Digital Banking Reflection and Zakat Accountability Sharia Banking in Indonesia

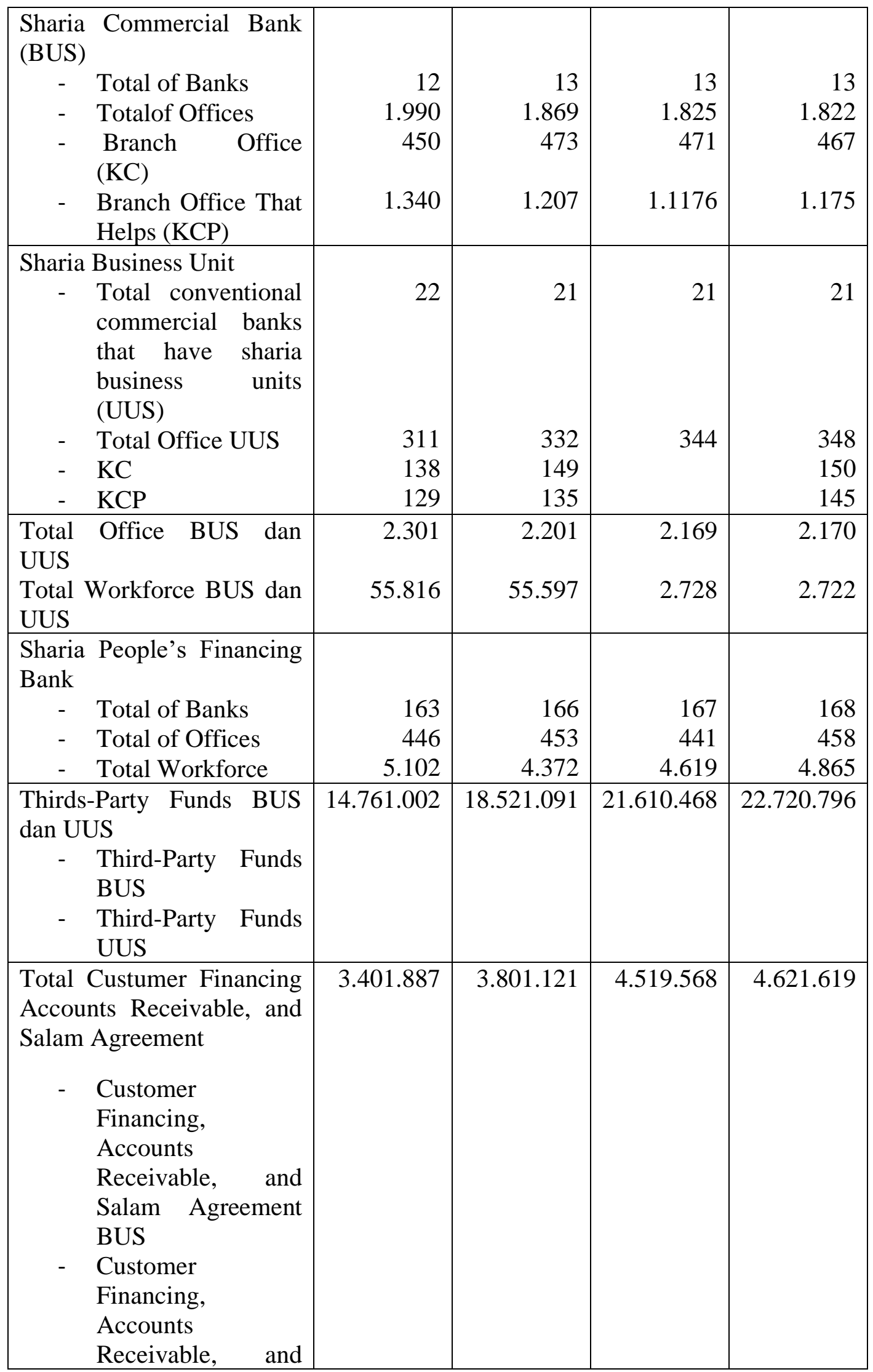


Pertiwi Utami:

Digital Banking Reflection and Zakat Accountability Sharia Banking in Indonesia

\begin{tabular}{|l|l|l|l|l|}
\hline $\begin{array}{l}\text { Salam Agreement } \\
\text { UUS }\end{array}$ & & & & \\
\hline
\end{tabular}

Source: Data processed,(Bank Licensing and Banking Information Departement Administrasion and Publikation Deputiy Director (IDAP), 2018)

On the one hand, the efforts carried out answer the challenges of the digitalization era in increasing the economic growth of the community but on the other hand it has an impact on the potential of zakat owned by the Islamic banking that needs to be taken into account. Not without reason, the development of digital technology greatly influences the use of human resources. ${ }^{8}$ If digital technology shifts the role of human resources, how can the sustainability of the muzaki zakat potential be empowered through internal sources (employees)? From table 1.1, it can be seen that there has been a drastic decline in Sharia labor force and Islamic banks from the following year and quite high potential for zakat, infaq and sadaqah (ZIS) originating from sharia banking customers in Indonesia.

In addition to the impact of digital technology on the potential of zakat, researchers also discussed the accountability of reports focusing on the zakat fund report. "Accountability of financial statements is an embodiment of accountability or accountability to stakeholders and Allah SWT". 9 The principles of sharia accounting can be seen in Al Quran (2): 282.

As Bank of Indonesia (BI) Regulation No. 14/14 / PBI / 2012 and Sharia Financial Services Authority Regulation No.6 / POJK.03 / 2015 as amended by the Financial Services Authority Regulation No.32 / PJOK.03 / 2016 concerning Transparency and Publication of Reports on Sharia Banks specifically required to deliver report on sources of Zakat, Infaq and Shadaqah Funds and the Financial Services Authority Circular Letter No.10 / SEOJK.03 / 2017 concerning "Transparency and Publication of Reports of Commercial Banks and Sharia Business Units". The bank also provides zakat fitrah services in collaboration with zakat institutions which will later be distributed to people in need.

In the April 2018 Sharia Banking Statistics Report released by the FSA (Bank Licensing and Banking Information Administration and Publication 
Pertiwi Utami:

Digital Banking Reflection and Zakat Accountability Sharia Banking in Indonesia

Department of Deputy Director ${ }^{10}$ there will not be found a total of total zakat funds received and realized. Information on zakat management reports can only be found in the annual report, sharia is different from tax. "There is no truly appropriate management of zakat property on the part of the government that affects the management of zakat itself, such as the right to apply zakat to Muslim citizens. Zakat management becomes less effective and efficient and can cause injustice to mustahik. ${ }^{11}$

Why is the potential of zakat which should have been able to be obtained from the Sharia Budget to date not be optimally realized? "The high governance of corporate zakat must be embedded in Islamic financial institutions to improve performance to be better". ${ }^{12}$ In addition, the disclosure of accountability reports on sources and uses of zakat funds made by the Sharia Commercial Banks and Sharia Business Units is limited to reports on external and internal zakat funds, not in detail. This can lead to public perceptions that the source of zakat is only obtained and managed from a small portion of zakat revenue, while the bank's own employees do not necessarily carry out their zakat income.

The purpose of this study is to answer the issues related to the impact of digital technology on labor or human resources, minimize the emergence of negative perceptions from the public on zakat management sources and funds reports by Islamic banking and provide results of literature studies to increase interest in paying zakah on Islamic banking. in Indonesia.

Research is expected to provide a reference to the science of good governance of amil zakat and strategic management based on sharia law on the performance of Islamic banking in terms of disclosure of reports on sources and management of zakat funds, and digital banking zakat services and empowerment of human resources. As the basic concept of sharia principles to realize maqasid sharia principles (the purpose of sharia law), namely maslahah ummah (community welfare).

"Literacy to increase muzaki's trust in the regulation of sharia with accountability and transparency in the management of zakat will have a positive influence on interest in paying zakat" "Financial reports are a reflection of good 
Pertíwi Utami:

Digital Banking Reflection and Zakat Accountability Sharia Banking in Indonesia

financial management". ${ }^{13}$ It seems that so far the standard of sharia has not fully applied the maqasid of sharia principles, especially the principle of justice in this matter regarding the management of corporate zakat. ${ }^{14}$

\section{WRITING METHOD}

The method of collecting documentation data comes from secondary data types obtained from various sources of information that are accurate and reliable. For example, the Central Bureau of Statistics Data and Statistical Data on Sharia Banks. In addition, the method of observation is done to see the extent of information (about what happened) and the context (related things around it). Then the editing method is done to get the alignment of the data that has been collected. Then developed using descriptive qualitative analysis techniques by exploring the disclosure of reports on sources and uses of zakat funds in sharia banking in Indonesia. Sharia banking is chosen as the object of research because it has the obligation to report zakat funds as PSAK 101 so that it makes it easier for researchers to obtain sources of information about the potential of zakat on banking based on these sharia principles. Then draw conclusions from the research results.

\section{RESULTS AND DISCUSSION}

Digital Banking services for zakat and Accountability for Zakat Management are part of efforts to increase interest in paying zakat in sharia financial institutions. In addition to the company's main objectives as agency theory (emphasizing stakeholder interests), the regulation of sharia cannot be separated from the purpose of the benefit of the people (community welfare). This means that maqasid ash sharia is a very important aspect in the management of zakat on the regulation of sharia itself. Based on previous research conducted by previous researchers, researchers reformulated in the form of a model of development efforts that can be done to increase the interest of muzaki to pay zakat through Islamic financial institutions, especially in this case as an alternative to overcome the problems that arise as previously described. As for the following: 
Pertiwi Utami:

Digital Banking Reflection and Zakat Accountability Sharia Banking in Indonesia

\section{A. Zakat Literacy}

Zakat literacy is very much needed considering that potential muzaki also comes from internal companies, namely employees of the bank itself, especially as a source of professional zakat. Muzaki must be given an understanding of the importance of the obligation to pay zakat and its benefits so that interest arises and zakat literacy

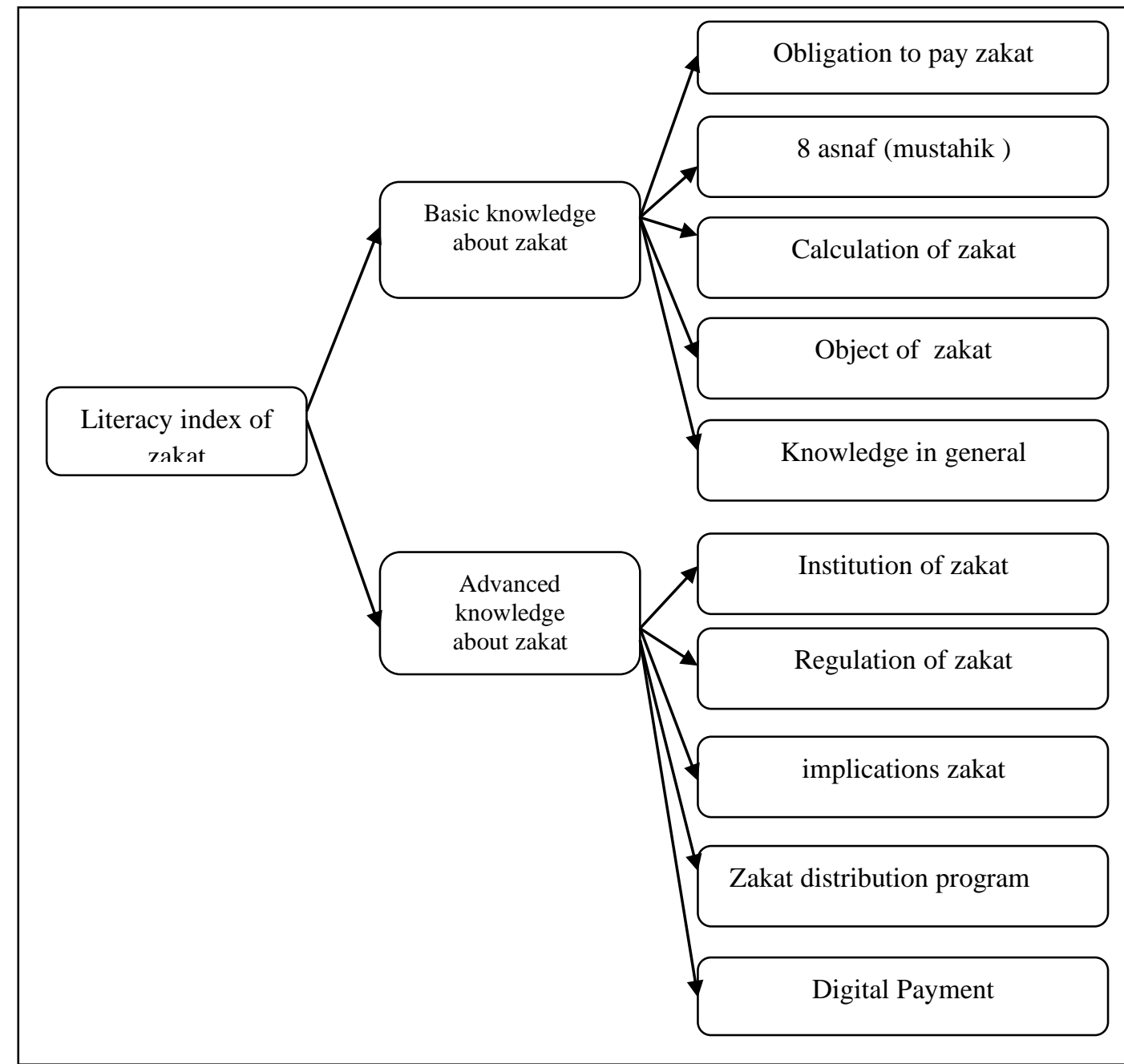

Figure 1.1 The instruments of zakat literacy Sumber:(BAZNAS, 2019) 
Pertíwi Utami:

Digital Banking Reflection and Zakat Accountability Sharia Banking in Indonesia

The results of the Zakat Literacy Index study above can be used as a standard measurement tool to determine the level of zakat literacy on Islamic banking so that it can be followed up and evaluate the performance of zakat resources and fund management to be even better.

\section{B. Transparency of Accountability in Information Presentation of Sources and Zakat Management Reports}

Transparency according to sharia principles is found in the Qur'an [14]: 4. "Allah sent each messenger to his people by using the language of his people, in order to explain their instructions and teachings. So that they understand and understand the point. Transparency in this case concerns the language delivered, so that all information can be easily understood and there is no mistake in its delivery."(Jonah, 1991)

"To realize transparency in the management of zakat, it must be adjusted to the principles of accountability as follows:

1. There is commitment from the leadership and all agency staff to make management and implementation accountable.

2. Guaranteed use of resources consistent with government laws and regulations.

3. Shows the level of achievement of the objectives and targets set.

4. Oriented to the vision and mission of banking sharia in accordance with sharia principles and the results and benefits obtained.

5. honesty, being objective, transparent, and innovative as a facilitator of changes in management of government agencies in the form of updating performance measurement methods and techniques and preparing accountability reports. "(LAN and BPKP, 2000)

Disclosure of reports on sources and funds of zakat management in addition to being open and easily accessible must also be easily understood by the intent and purpose. With clear disclosures such as the disclosure of the amount of internal and external muzaki both zakat fitrah, zakat maal and professional zakat 
Pertiwi Utami:

Digital Banking Reflection and Zakat Accountability Sharia Banking in Indonesia

received to prevent negative perceptions and increase public trust in the management of Islamic zakat, so that interest in paying zakat is expected to increase. As explained in the form of the following scheme:

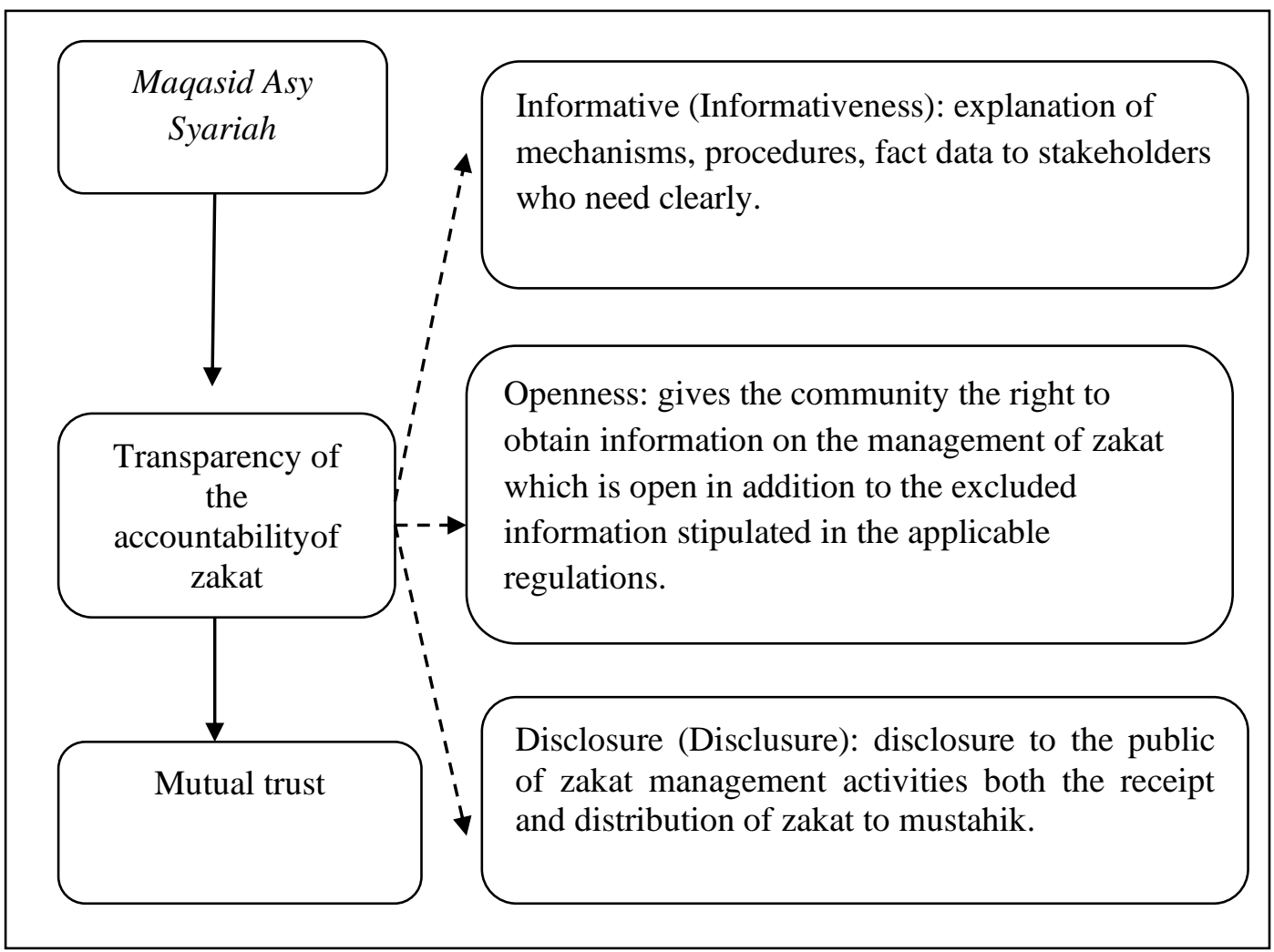

Figure 1.2 Transparency of the Accontability of zakat Source: (Mardiasmo,2004)

As indicators for measuring accountability can be developed for the accountability of zakat. Following is the development model and a brief explanation: 
Pertiwi Utami:

Digital Banking Reflection and Zakat Accountability Sharia Banking in Indonesia

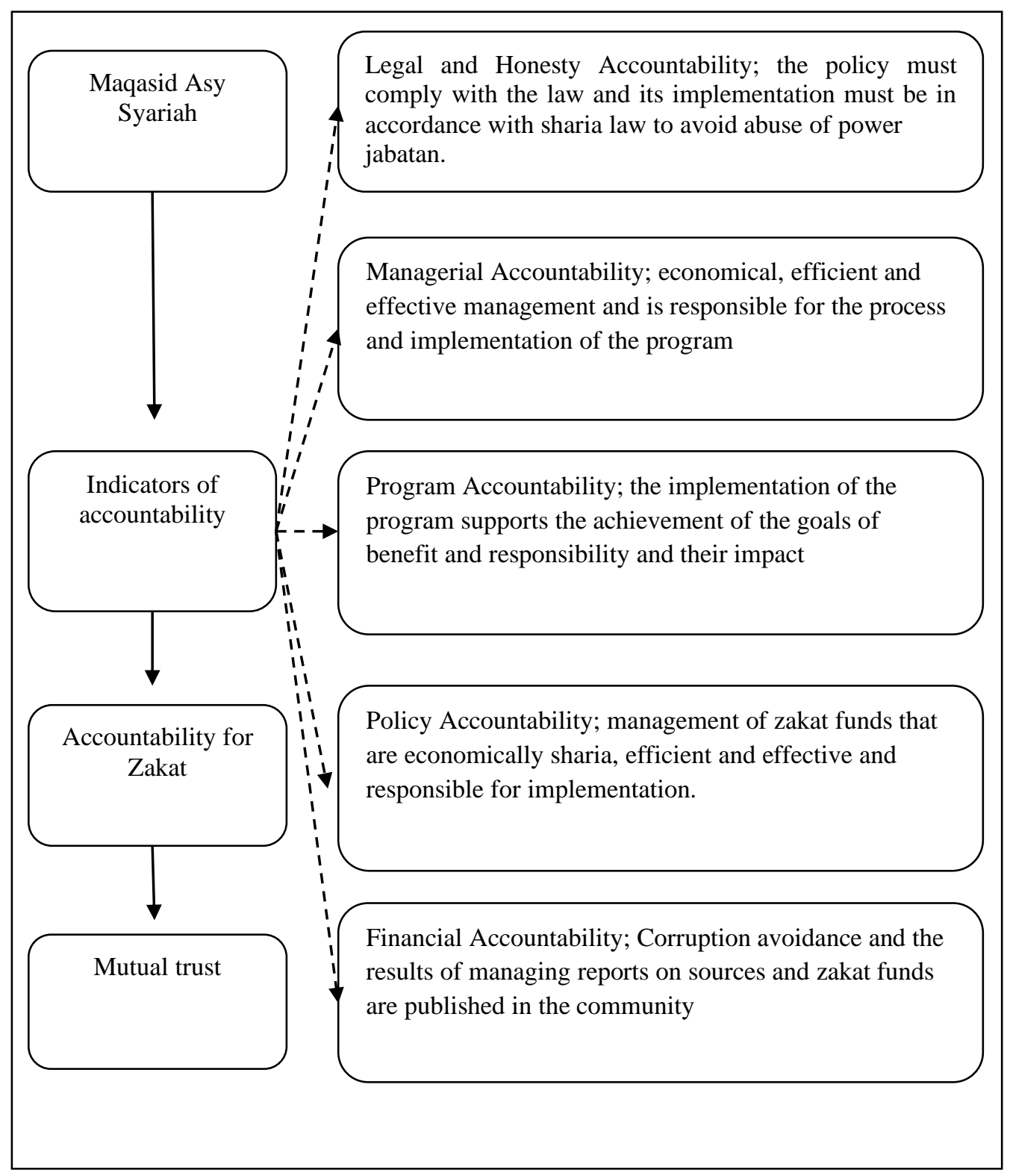

Source: (Hopwood dan Tomkins,1984; Elwood,1993)

Figure 1.3 Indicators of Zakat Accountability

\section{Acceleration and Optimization of Zakat Management}

Acceleration efforts are one of the strategic management steps that are often carried out by banking sharia in Indonesia. While optimization cannot be done without internal cooperation, zakat institutions and the role of the government. All three must work together in order to realize public welfare. 
Pertiwi Utami:

Digital Banking Reflection and Zakat Accountability Sharia Banking in Indonesia

Through the right indicators, acceleration and optimization can be done effectively. There are 4 steps of acceleration and optimization that can be done to overcome the problem of negative influences from the development of digital technology today, along with the explanation:

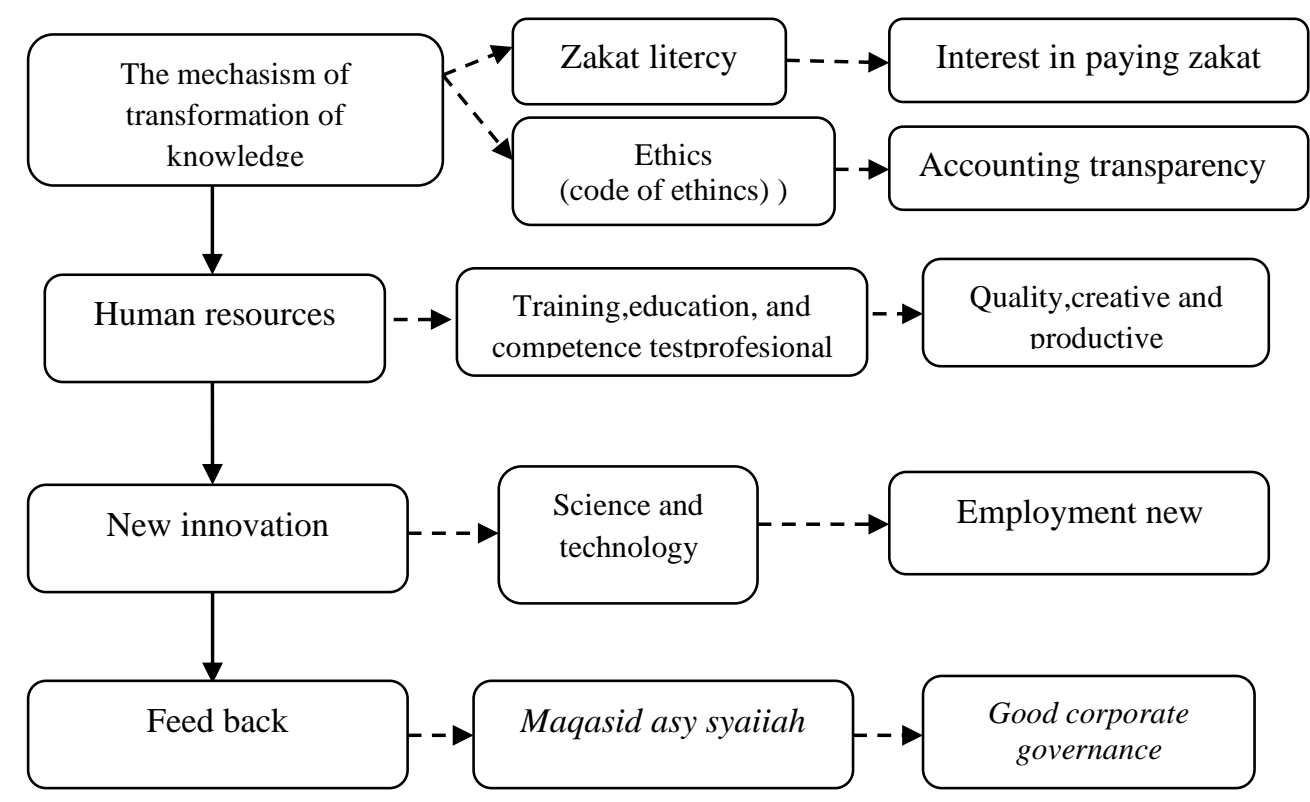

Figure 3 Acceleration and Optimization of Zakat Management Source:(Utami, 2019a), (Utami, 2019b)

1. Knowledge Information Mechanism

The process of transforming knowledge can be done by increasing zakat literacy and understanding and application of ethical / ethical codes that are in accordance with the principles of sharia law and government regulations.

2. Acceleration and optimization of human resources

Empowerment of human resources is an absolute requirement, with proper training, competency testing and education human resources create quality, creative and productive human resources so that technology can be used more wisely without having to shift the role of HR.

3. Acceleration of new innovations and product quality optimazation

The acceleration of new innovations aims at the development of Science and Technology needed to improve the performance of Islamic finance, including in terms of optimizing the use of digital technology in zakat service products. 
Pertíwi Utami:

Digital Banking Reflection and Zakat Accountability Sharia Banking in Indonesia

It is expected that the mechanism carried out can create new jobs so that the potential of muzaki will continue to increase.

4. Feedback acceleration

To produce achievement of measurable potential, comprehensive feedback management is needed. Evaluation media by collaborating professionally will be able to realize good corporate governance.

\section{CONCLUSION}

Disclosure of reports on sources and management of zakat funds that are truly transparent and understandable to the public can reduce negative perceptions in the community. Zakat which is essentially a manifestation of the worship of the Almighty God should have been arranged as well as possible in accordance with maqasid asy sharia. Technology development must be wisely applied in the performance of Islamic financial institutions. So that it does not shift the role of human resources which should be prioritized. By way of empowering the quality of human resources through zakat literacy, acceleration and optimization that is effectively and efficiently expected to increase interest in paying zakat on sharia banking in Indonesia.

As the researcher have revealed, the main problem of this study is the impact of digital banking on the economic sustainability of labor or human resources and the transparency of disclosure of accountability for zakat in sharia in Indonesia. Therefore, the advice that researchers can convey is related to the importance of zakat literacy in the company's internal. Sharia financial institutions must further increase zakat literacy so that good corporate governance in accordance with sharia law can be realized. So the potential that can cause negative issues in the community will disappear by itself. The role of government regulation is highly expected in terms of making policies that support efforts to increase the potential of zakat in sharia banking in Indonesia. 
Pertíwi Utami:

Digital Banking Reflection and Zakat Accountability Sharia Banking in Indonesia

\section{Endnotes}

${ }^{1}$ Ansori, A. (2016). digitalization of Islamic Economics. IAIN Sultan Maulana Hasanuddin Banten. Islamic financial and Business Economics Journals, 7(1), 1-18.

2 Vives, X. (2019). Competition and Stability in Modern Banking: A Post-Crisis Perspective. International Journal of Industrial Organization. Retrieved from: https://doi.org/10.1016/j.ijindorg.2018.08.011

${ }^{3}$ Dz, A. S. (2018). Digital Banking Based Islamic Inclution:Optimization and Challenges, Journal of Islamic Studies and Banking Sharia (Al-AMWAL),10(1).10(1).Retrieved from http://dx.doi.org/10.24235/amwal.v10i1.2813.

${ }^{4}$ Baabdullah, A. M., Alalwan, A. A., Rana, N. P., Kizgin, H., \& Patil, P. (2019). Consumer use of mobile banking (M-Banking) in Saudi Arabia: Towards an integrated model. International Journal of Information Management, 44(August 2018), 38-52. Retrieved from: https://doi.org/10.1016/j.ijinfomgt.2018.09.002

${ }^{5}$ Shaikh, A. A., Glavee-Geo, R., \& Karjaluoto, H. (2017). Exploring the nexus between financial sector reforms and the emergence of digital banking culture - Evidences from a developing country. Research in International Business and Finance, 42(June), 1030-1039. Retrieved from: https://doi.org/10.1016/j.ribaf.2017.07.039

${ }^{6}$ Alam Choudhury, M., \& Nurul Alam, M. (2013). Corporate governance in Islamic perspective. International Journal of Islamic and Middle Eastern Finance and Management, 6(3), 180-199. Retrieved from: https://doi.org/10.1108/IMEFM-10-2012-0101

${ }^{7}$ Bank Licensing and Banking Information Departement Administrasion and Publikation Deputiy Director (IDAP). (2018). Syariah Statistics Banking 2018, 1-104. Retrieved from www.ojk.go.id

${ }^{8}$ Idrus, S. (2018). Perspective on tourism human resources in the Age of the Industrial Revolution 4.0. In ProcedingSINTESA2 Nov 2012 (pp. 587-594).

9 Saad, R. A. J., Aziz, N. M. A., \& Sawandi, N. (2015). Islamic Accountability Framework in the Zakat Funds Management. Procedia - Social and Behavioral Sciences, 164(August), 508-515. Retrieved from: https://doi.org/10.1016/j.sbspro.2014.11.139

${ }^{10}$ Bank Licensing and Banking Information Departement Administrasion and Publikation Deputiy Director (IDAP). (2018). Syariah Statistics Banking 2018, 1-104. Retrieved from www.ojk.go.id

${ }^{11}$ Ali, K. M., Ali, Z. M., Ahmad, S., \& Zain, M. N. M. (2017). The Concept and the Accountable Authority in Zakah Management. Islamiyyat, 39(1), 3-9.

${ }^{12}$ Rashid, M. A. dan S. K. (2016). The need for high corporate governance in nigerian zakāh and waqf institutions. Jurnal Syariah, 24(3), 495-526.

${ }^{13}$ Nurhasanah, S. (2018). Accountability of Financial Statements Amil Zakat Institutions in Maximizing the Potential of Zakat. Akuntabilitas, 11(2), 327-348. Retrieved from: https://doi.org/10.15408/akt.v11i2.8826

${ }^{14}$ Birton, M. N. A., Triyuwono, I., Mulawarman, A. D., \& Rahman, A. F. (2015). Theory of Shariahization on Conceptual Accounting Framework: A Substantive Theory. Procedia - Social and Behavioral Sciences, 211, 723-730. Retrieved from: https://doi.org/10.1016/j.sbspro.2015.11.093 
Pertíwi Utami:

Digital Banking Reflection and Zakat Accountability Sharia Banking in Indonesia

\section{BIBLIOGRAPHY}

Alam Choudhury, M., \& Nurul Alam, M. (2013). Corporate governance in Islamic perspective. International Journal of Islamic and Middle Eastern Finance and Management, 6(3), 180-199. Retrieved from: https://doi.org/10.1108/IMEFM-10-2012-0101

Ali, K. M., Ali, Z. M., Ahmad, S., \& Zain, M. N. M. (2017). The Concept and the Accountable Authority in Zakah Management. Islamiyyat, 39(1), 3-9.

Ansori, A. (2016). digitalization of Islamic Economics. IAIN Sultan Maulana Hasanuddin Banten. Islamic financial and Business Economics Journals, 7(1), 1-18.

Baabdullah, A. M., Alalwan, A. A., Rana, N. P., Kizgin, H., \& Patil, P. (2019). Consumer use of mobile banking (M-Banking) in Saudi Arabia: Towards an integrated model. International Journal of Information Management, 44(August 2018), 38-52. Retrieved from: https://doi.org/10.1016/j.ijinfomgt.2018.09.002

Bank Licensing and Banking Information Departement Administrasion and Publikation Deputiy Director (IDAP). (2018). Syariah Statistics Banking 2018, 1-104. Retrieved from www.ojk.go.id

BAZNAS, P. K. S. (2019). Indeks Literasi Zakat:Teori dan Konsep. Jakarta Pusat: Pusat Kajian Strategis.

Birton, M. N. A. (2016). Maqasid Syariah as a Method of Building the Purpose of Sharia Entity Financial Statements. Multiparadigma Accounting Jounal, 6(3), 421-431. Retrieved from: https://doi.org/10.18202/jamal.2015.12.6034

Birton, M. N. A., Triyuwono, I., Mulawarman, A. D., \& Rahman, A. F. (2015). Theory of Shariahization on Conceptual Accounting Framework: A Substantive Theory. Procedia - Social and Behavioral Sciences, 211, 723730. Retrieved from: https://doi.org/10.1016/j.sbspro.2015.11.093

Dz, A. S. (2018). Digital Banking Based Islamic Inclution:Optimization and Challenges, Journal of Islamic Studies and Banking Sharia (AlAMWAL), 10(1).10(1).Retrieved from http://dx.doi.org/10.24235/amwal.v10i1.2813.

Idrus, S. (2018). Perspective on tourism human resources in the Age of the Industrial Revolution 4.0. In ProcedingSINTESA2 Nov 2012 (pp. 587594).

Financial Fervices Authority (OJK).. (2018). Organizing Digital Banking Services 
Pertíwi Utami:

Digital Banking Reflection and Zakat Accountability Sharia Banking in Indonesia

by Commercial Banks. Jakarta: OJK. Retrieved from: https://www.ojk.go.id/id/regulasi/Pages/Penyelenggaraan-LayananPerbankan-Digital-oleh-Bank-Umum.aspx

Mandiri, B. S. (2019). Financia.l Statements of PT. Bank Mandiri \& Parent Company, Jakarta: Central Office of Bank Mandiri. 14040.

Muñoz, L. F, Climent, C.S., \& Liébana, C.F. (2017). Determinants of intention to use the mobile banking apps: An extension of the classic TAM model. Spanish Journal of Marketing - ESIC, 21(1), 25-38. Retrieved from: https://doi.org/10.1016/j.sjme.2016.12.001

Nurhasanah, S. (2018). Accountability of Financial Statements Amil Zakat Institutions in Maximizing the Potential of Zakat. Akuntabilitas, 11(2), 327-348. Retrieved from: https://doi.org/10.15408/akt.v11i2.8826

Rahim, S., \& Sahrullah, S. (2017). Corporate Zakat Management Model. Multiparadigma Accounting Journal, 200-215. Retrieved from: https://doi.org/10.18202/jamal.2017.04.7049

Rashid, M. A. dan S. K. (2016). The need for high corporate governance in nigerian zakāh and waqf institutions. Jurnal Syariah, 24(3), 495-526.

Saad, R. A. J., Aziz, N. M. A., \& Sawandi, N. (2015). Islamic Accountability Framework in the Zakat Funds Management. Procedia - Social and Behavioral Sciences, 164(August), 508-515. Retrieved from: https://doi.org/10.1016/j.sbspro.2014.11.139

Shaikh, A. A., Glavee-Geo, R., \& Karjaluoto, H. (2017). Exploring the nexus between financial sector reforms and the emergence of digital banking culture - Evidences from a developing country. Research in International Business and Finance, 42(June), 1030-1039. Retrieved from: https://doi.org/10.1016/j.ribaf.2017.07.039

Utami, P. (2019a). Optimization of Utilization of E-Commerce on Halal Products in Indonesia, Eastern Jornal of Economics and Finance, 4(1), 14-23. Retrieved from: https://doi.org/10.20448/809.4.1.14.23

Utami, P. (2019b). Strategic Management in the Zakat Growth Acceleration Framework in Indonesia, , International Journal of Economics, Business and Management Studies,6(2), 149-158. Retrieved from: https://doi.org/10.20448/802.62.149.158

Vebiana, V. (n.d.). Digital Banking, Custumer Experience and Financial Performenace of Islamic Banks. Proceding: In 9th Industrial Research Workshop and National Seminar (pp. 747-751). 
Pertiwi Utami:

Digital Banking Reflection and Zakat Accountability Sharia Banking in Indonesia

Vives, X. (2019). Competition and Stability in Modern Banking: A Post-Crisis Perspective. International Journal of Industrial Organization. Retrieved from: https://doi.org/10.1016/j.ijindorg.2018.08.011 